\title{
Protein Wnt-7a
}

National Cancer Institute

\section{Source}

National Cancer Institute. Protein Wnt-7a. NCI Thesaurus. Code C17919.

Protein Wnt-7a (349 aa, $39 \mathrm{kDa}$ ) is encoded by the human WNT 7A gene. This protein plays a role in intercellular communication and the regulation of cell fate and patterning during embryogenesis. 